\title{
PENGEMBANGAN BAHAN AJAR MUATAN LOKAL BAHASA BUOL UNTUK SEKOLAH DASAR KELAS 1 SEMESTER 1 DI KABUPATEN BUOL
}

\section{(THE DEVELOPMENT OF LEARNING MATERIALS FOR A LOCAL CONTENT LANGUAGE BUOL ELEMENTARY SCHOOL GRADE 1 SEMESTER 1 IN BUOL)}

\author{
Hariyanto S. Auna ${ }^{1}$, Sulton ${ }^{2}$, dan Saida Ulfa ${ }^{3}$ \\ Universitas Negeri Malang \\ E-mail: ${ }^{1}$ haryanto.auna@ gmail.com, ${ }^{2}$ sulton.um@gmail.com, ${ }^{3}$ saida.ulfa@gmail.com
}

\begin{abstract}
Abstrak: Penelitian pengembangan bahan ajar muatan lokal bahasa Buol didasarkan pada kondisi bahasa Buol yang terpenetrasi dengan bahasa daerah lain serta kebutuhan daerah dalam implementasi pembelajaran muatan lokal yang sesuai dengan karateristik daerah. Tujuan pengembangan bahan ajar muatan lokal bahasa Buol adalah untuk menghasilkan bahan ajar bahasa Buol yang dapat memfasilitasi pembelajaran dalam rangka pembentukan minat belajar Bahasa Buol dan kemampuan berbahasa Buol, sehingga bahan ajar ini dikembangkan berdasarakan kegiatankegiatan kognitif. Dari hasi validasi ahli bahan ajar muatan lokal bahasa Buol dikategorikan layak dan hasil uji coba telah memenuhi kriteria yang diharapkan. Sehingga bahan ajar muatan lokal bahasa Buol sudah suseuai dengan kreiteria kelayakan untuk digunakan oleh siswa kelas 1 semeseter 1 Sekolah Dasar di Kabupaten Buol.
\end{abstract}

Kata Kunci: Pengembangan Bahan Ajar, Muatan Lokal, Bahasa Buol, Kognitif

\begin{abstract}
The study material development of local content based on the language Buol Buol language conditions are penetrated by other regional languages as well as the learning needs of the region in the implementation of local content in accordance with local characteristics. The purpose of the development of language teaching materials Buol local content is to generate Buol language teaching materials that can facilitate learning in order to create interest in learning English Buol Buol and language skills, so that teaching material was developed on the terms of cognitive activities. Hasi validation of local content experts instructional materials categorized Buol language decent and test results have met the criteria expected. So that the local content of language teaching materials Buol had suseuai with kreiteria eligibility for use by students in grade 1 semeseter 1 Primary School in Buol.
\end{abstract}

Keywords: Development Of Learning Materials, Local Content, Language Of Buol, Cognitive

Keanekaragaman bahasa tidak dapat sanya. Di Indonesia bahasa daerah hidup dipisahkan dari keanekaragaman budaya. berdampingan dengan bahasa Indonesia, Kebudayaan merupakan satu sistem bahasa asing tertentu dan bahasa daerah yang mengatur interaksi manusia di lain. Dalam kontak sosial sudah tentu dalam masyarakat. Sehingga kebaha- tidak terhindarkan adanya saling memesaan adalah suatu sistem yang berfu- ngaruhi di antara bahasa-bahasa yang ngsi sebagai sarana. Sistem bahasa terlibat kontak. Bahasa yang kuat akan mempunyai fungsi sebagai sarana untuk bertahan dan mempersempit ruang gerak berlangsungnya interaksi manusia di bahasa-bahasa lain yang berkeadaan dalam masyarakat. Artinya berbahasa lemah. Dalam aertikel UNESCO (2009), haruslah disertai norma-norma yang mempublikasikan bahawa ahli bahasa berlaku di dalam budaya itu sendiri. percaya bahwa sebagian besar bahasa di Seperti yang dikatakan oleh Chaer dunia akan punah dalam abad ini. (2003), bahwa jalan pikiran dan Setengah dari bahasa yang ada sekarang kebudayaan suatu masyarakat ditentu- (diperkirakan antara 6.000 sampai 8.000 kan atau dipengaruhi oleh struktur baha- bahasa) dituturkan oleh kurang dari 
10.000 orang, dan satu dari bahasa yang kita". Walau secara umum masyarakat semacam ini dikatakan punah setiap dua Paleleh menggunakan bahasa "nganaminggu. ngana, kita-kita", tetapi masyarakat Peleleh masih bisa mengerti dengan

Dalam ilmu sosiolinguistik stru- bahasa Buol. Hanya saja permasaktur masyarakat selalu bersifat heterogen lahannya mereka sangat kesulitan dalam memengaruhi struktur bahasa. Struktur mengucapkan kalimat bahasa Buol. masyarakat dipengaruhi berbagai faktor. Kesulitan tersebut ternyata dipengaruhi Misalnya, siapa yang berbicara, dengan oleh ketidakmampuan dalam memahami siapa berbicara, kapan berbicara, dimana, struktur bahasa Buol antaranya; 1) dan untuk apa (Wijana, 2005). Begitu fonologi yaitu cara mengintonasikan juga di daerah Buol yang memiliki kalimat dalam bahasa Buol yang masyarakat yang heterogen. Masyarakat dipengaruhi oleh intonasi bahasa Buol dipengaruhi oleh beberapa budaya Gorontalo dan Manado, 2) merfologi seperti, budaya Bugis, Manado, yaitu kesulitan dalam penggunaan bentuk Gorontalo dan Kaili (Kaseng, Masjhuda, kata, dimana masyarakat sulit menuWumbu, Lumentut, Kadir, dan Rozali, liskan kata dan mengucapkannya, 3) 1979). sintaksis dan sumatif yaitu kesulitan dalam penulisan kalimat dan pemaknaan

Bahasa Buol adalah bahasa kalimat, sehingga terjadi campur baur daerah yang dipakai dibagian utara bahsa dalam kalimat.

Sulawesi Tengah dalam wilayah seluas \pm

$4.300 \mathrm{~km}$ persegi, yang meliputi Permasalahan yang paling menKecamatan Paleleh, Kecamatan Buno- dasar yang terjadi yaitu pemaknaan kata bogu, Kecamatan Biau, Kecamatan dan kalimat serta intonasi. Salah satu Bokat, Kecamatan Momunu, dan kasus yang diamati oleh peneliti yaitu Kecamatan Gadung (Garancang, Kadir, berupa kata "gantung”. Dari hasil penKajia dan Mahmud, 1986 dan UU RI No gamatan bahwa kata tersebut terjadi 5 Tahun 1999). Sepanjang sejarahnya banyak penggunaan kata dalam bahasa penduduk Buol merupakan suatu kesatuan Buol. Ada yang mengatakan "tili-tili", yang erat. Penduduk Buol merupakan "gogandong, dan "tado-tado". Begitu masyarakat pemakai bahasa Buol yang juga masalah intonasi bahasa dimana sampai dewasa ini hanya memiliki satu terjadi perbedaan intonasi antara dialeg (Garancang, Kadir, Kajia dan masyarakat perbatasan, perkotaan dan Mahmud, 1986). daerah terpencil.

Di kabupaten Buol ada beberapa Permasalah bahasa Buol semakin wilayah yang sudah mulai terancam jelas dirasakan, khususnya oleh para punah bahasa Buol, diantaranya yaitu tokoh adat dan pemerintah Daerah. Desa Paleleh dan Desa Lakukan. Walau sekarang daerah telah memiliki Wilayah Desa Paleleh berada dibagian kamus bahasa Buol, tetapi belum utara Buol. Wilayah tersebut berdekatan lengkap jika pelestarian bahasa Buol dengan daerah Gorontalo dan Manado. belum dilakukan melalui pendidikan. Hal Bahasa Buol di daerah Paleleh sangat tersebut diungkapkan oleh tokoh adat dan jarang didengarkan. Penetrasi bahasa pihak-pihak pemerintah daerah antara bahasa Gorontalo dan bahasa Kabupaten Buol dalam wawancara Manado, sangat terasa di daerah Paleleh, langsung. Pendidikan muatan lokal di sehingga masyarakat paleleh mengis- daerah Kabupaten Buol belum berjalan, tilahkan dengan "ngana-ngana, kita- akibatnya beberapa sekolah di Kabupaten 
Buol banyak yang tidak melaksanakan Perkembangan pikiran individu tampak pembelajaran muatan lokal. Mungkin dalam perkembangan bahasanya yaitu ada, tetapi tidak sesaui dengan tujuan kemampuan membentuk pengertian, muatan lokal. Contoh kasus di satu menyusun pendapat, dan menarik sekolah yang memanfaatkan belajar kesimpulan. Menurut Vygotsky pada muatan lokal dengan belajar bahasa mulanya bahasa dan pikiran anak Inggris.

berbeda. Kemudian secara perlahan, sesuai tahap perkembangan mentalnya,

Program pendidikan di sekolah bahasa dan pikiran menyatu sehingga perlu memberikan wawasan yang luas bahasa merupakan ungkapan dari pada peserta didik tentang kekhususan pikiran. Anak secara alami belajar yang ada di lingkungannya. Untuk bahasa dari interaksinya dengan orang mewujudkan pendidikan muatan lokal, lain untuk berkomunikasi, yaitu daerah perlu mengembangkan sumber menyatakan pikiran dan keinginannya belajar. Salah satunya adalah bahan ajar, serta memahami pikiran dan keinginan sehingga perlu dibutuhkan sumber orang lain (Santrock, 2004).

belajar bahasa Buol yang berbasis pada

muatan lokal. Perlindungan Bahasa Kita mengetahui bahwa budaya adalah upaya menjaga dan memelihara berperan penting dengan menentukan kelestarian bahasa melalui penelitian, perangkat bahasa yang dibutuhkan pengembangan, pembinaan, dan penga- dalam kehidupan orang-orang. Setiap jarannya (Peraturan Pemerintah No 57 insan memiliki potensi yang sama untuk Tahun 2014).

Undang- undang Nomor 20 menguasai bahasa. Proses dan sifat penguasaan bahasa setiap orang ber20 langsung dinamis dan melalui tahapan Tahun 2003 tentang Sistem Pendidikan berjenjang. Manusia mengawali komuNasional, merupakan bahan kajian yang nikasinya dengan dunia sekitarnya dimaksudkan untuk membentuk melalui bahasa tangis. Melatih bahasa pemahaman peserta didik terhadap tersebut seorang bayi mengkomupotensi di daerah tempat tinggalnya. nikasikan segala kebutuhan dan Dalam Pasal 79 N Peraturan Pemerintah keinginannya. Sejalan dengan perkemNomor 32 Tahun 2013 tentang bangan kemampuan serta kematangan Perubahan Atas Peraturan Pemerintah jasmani terutama yang bertalian dengan Nomor 19 Tahun 2005 tentang Standar proses bicara, komunikasi tersebut Nasional dinyatakan bahwa : (1) makin meningkat dan meluas. Misalnya muatan lokal untuk setiap satuan dengan orang di sekitarnya lingkungan pendidikan berisi muatan dan proses dan berkembang dengan orang lain yang pembelajaran tentang potensi dan baru dikenal dan bersahabat dengannya. keunikan lokal; (2) muatan lokal dikembangkan dan dilaksanakan pada Dalam UU No. 2 tahun 1989 setiap satuan pendidikan. Kebijakan dikemukakan bahwa, pendidikan yang berkaitan dengan dimasukkannya dasar diselenggarakan untuk mengemprogram muatan lokal dalam standar isi, bangkan sikap dan kemampuan serta dilandasi kenyataan bahwa di Indonesia memberikan pengetahuan dan keteraterdapat beranekaragam kebudayaan. mpilan dasar yang diperlukan untuk hidup dalam masyarakat. Selain itu

Bahasa sangat erat kaitannya perkembangan bahasa anak-anak selama dengan perkembangan berfikir individu. usia sekolah pada usia 5 atau 6 tahun, 
kebanyakan sudah mengenal dasar-dasar bahasa daerah dalam memperkaya bahasa aslinya.

kebudayaan Indonesia. Salah satunya mengembangkan bahan ajar muatan

Anak- anak mengembangkan Lokal Bahasa Buol untuk Sekolah Dasar bahasa selama mereka membangun (SD).

kemampuan kognitif. Secara aktif anak-

anak memahami apa yang mereka Dengan demikian peneliti dengar, mencari pola-pola dan menyusun melakukan penelitian pengembangan aturan-aturannya. Berdasarkan rentang bahan ajar muatan lokal bahasa Buol usia, siswa kelas I Sekolah Dasar (SD) dengan bentuk cetak dengan tujuan berada pada tahap operasional konkret untuk menghasilkan produk bahan ajar artinya sangat membutuhkan model muatan lokal bahasa Buol yang sesuai untuk memahami konsep tertentu dengan kebutuhan serta karakteristik (Permatasari, 2012). Tahap operasional siswa Sekolah Dasar (SD) kelas 1 konkret yaitu jenjang usia 6 hingga 12 semester 1 di Kabupaten Buol. Produk tahun. Salah satu tugas penting yang ini diharapakan dapat membantu siswa dipelajari anak-anak selama tahap memiliki kemampuan dalam berbahasa operasional ialah pengurutan, atau Buol, sehingga produk ini dikemmenyusun sesuatu dalam bentuk logis bangkan dengan aspek-aspek kognitf. (Slavin, 2008).

Kualitas pembelajaran amat banyak tergantung pada bagaimana pembelajaran itu dirancang (Degeng, 1993). Organisasi dari segi konsep adalah sebagai suatu sistem yang dirancang untuk mencapai sasaran dan tujuan yang telah dicapai sebelumnya melalui orang-orang dan sumber dayasumber daya mereka pergunakan (Kendall dan Kendall, 2003). Bahan ajar yang didasarkan kebutuhan memenuhi tujuan dari kurikulum sekolah (Syatriana, Husain, Haryanto dan Jabu, 2013). Dijelaskan dalam Peraturan Pemerintah No 79 tahun 2014, bahwa mutan lokal dapat berupa bahasa daerah dan dapat dirumuskan dengan bentu buku teks pelajaran.

Bahasa daerah adalah aset yang berharga bagi Indonesia. Oleh karena itu, sudah saatnya para pemangku kepentingan di bidang kebahasaan ini secara ikhlas melakukan upaya pelestarian dengan kapasitas dan peran masing-masing. Dengan revitalisasi bahasa daerah otomatis akan meningkatkan daya hidup dan daya ungkap

\section{METODE}

Penelitian ini akan dilakukan di SDN 10 Paleleh kelas I semester 1 di Kabupaten Buol. Model pengembangan yang digunakan yaitu model Dick \& Carey sampai pada tahap evaluasi formatif. Prosedur pengembangan buku ajar ini ditempu melali beberapa tahap yaitu; 1) tahap studi pendahuluan dengankukan analisis, 2) tahap perancangan dengan melakukan kegiatan menyusun materi-materi pembelajaran 3) tahap evaluasi dengan melakukan analisis kelayakan produk melalui ahli dan uji coba produk, dan 4) melakukan revisi produk dari hasil validasi ahli dan uji coba.

\section{HASIL DAN PEMBAHASAN}

Pengembangan bahan ajar
muatan lokal bahasa Buol didasarkan
pada kenyataan bahwa belum
tersedianya buku ajar di daerah
Kabupatn Buol. Hasil pengembangan ini
dimaksudkan untuk memenuhi tersedia
buku ajar yang dapat meningkatkan
kemampuan berbahasa Buol.


Pengembangan bahan ajar dikembangkan berdasarkan pendekatan kognitif. Hasil tersebut dapat dilihat dari beberapa keunikan-keunikan bahan ajar sebagia berikut.

1. Pembelajaran dengan menggunakan buku ajar sebagai salah satu bagian dari strategi pengorganisasian isi pembelajaran memiliki tingkat keefektifan yang sistematik, sehingga kompotensi-kompotensi yang ada dalam bahan ajar disesuai dengan tingkat kemampuan yang akan di ajarkan.

2. Pembelajaran yang diterapkan dalam bahan ajar dikembangkan untuk menemukan kegiatan-kegiatan dan aktivitas-aktivitas yang sesuai dengan kebutuhan siswa.

3. Gambar-gambar yang ada dalam bahan ajar digunakan untuk membangun pesan visual terhadap aktivitas-aktivitas dan kegiatankagiatan yang akan dipelajarai.

4. Penggunaan gambar kartun dikarenakan hasil analisis perilaku siswa lebih cepat mengenali gambargambar yang berbentuk kartun dibandingkan foto. Hal tersebut dikarenakan unsur visual kartun memiliki warna dan corak yang kurang, dibandingkan foto yang memiliki banyak warna, misalnya foto wajah dan pemandangan serta gambar yang memiliki gradient warna.

5. Pada tujuan khusus pembelajaran lisasi

dirancang dengan menggunakan

proses kognitif melalui tahap mengingat, memahami, mengapli-
kasikan, menganalisis, mengevaluasi dan mencipta. 6. Untuk mengukur keberhasilan dalam pembelajaran, ahli desain pembelajaran, bahan ajar ini, lebih ditekankan pada dan pengamatan guru terhadap siswa pengamatan proses kognitif. Hal dalam kegiatan uji coba. Aspek yang tersebut dikarenakan strategi penya- diungkap untuk melakukan revisi mpaian lebih pada kegiatan dan meliputi unsur kelayakan menurut ahli aktivitas belajar, sehingga siswa tidak dipaksakan untuk menghafal.

7. Dengan evaluasi proses siswa tidak selalu dibebankan pada evaluasi berbentuk teks, tetapi setiap kegiatan dan aktivitas siswa merupakan bagian dari keefektifan pembelajaran.

Produk pengembangan yang dikembangkan memiliki kelebihan dan keterbatasan. Kelebihan buku ajar ini diantaranya; 1) buku ini menyajikan strategi pembelajaran yang membantu siswa meningkatkan kemampuan berbahasa Buol melalui proses kognitif, 2) buku ini menyajikan kegiatan dan aktivitas sesuai dengan kebutuhan siswa, sehingga minat belajar siswa terdorong, 3) dengan evaluasi proses dan latihan alui kegiatan-kegiatan pada bahan ini, sehingga siswa tidak dipaksakan uk menghafal, dan 4) bahan ajar ini bahasa Buol yang pertama dikembangkan untuk siswa kelas 1 Sekolah Dasar, sehingga bahan ajar ini mendapat dukungan dari pihak berkepentingan . Dari kelebihan-kelebihan yang ada, bahan ajar ini tak luput dari keterbatasan diantaranya yaitu; 1) bahan ajar ini dikembangkan disaat masih kurangnya referensi ahli dan bahan di daerah Buol, sehingga kompotensi dan standar kompotensi dirancang melalui kesepakatan, dan 2) belumnya ada guru bahasa Buol, sehingga pengaplikasian perlu sosia-

Produk pengembangan buku ajar ini telah dilakukan penyempurnaan secara bertahap melalui review, penilaian ahli bahasa Buol, ahli media 
dan siswa serta pengamatan keefektifan lampangan. Berikut adalah kategoridan kemenarikan melalui pengamatan kategori dalam evaluasi:

kegiatan uji coba kelompok dan uji coba

\begin{tabular}{|c|c|c|c|c|}
\hline No & Subjek Uji Coba & Kategori & Tujuan evaluasi & $\begin{array}{c}\text { Hasil } \\
(\%)\end{array}$ \\
\hline 1 & Ahli Materi & Kelayakan Materi & $\begin{array}{l}\text { Untuk mengamati apakah materi- } \\
\text { materi tersebut sesuai untuk tipe hasil } \\
\text { belajar }\end{array}$ & 93,5 \\
\hline 2 & $\begin{array}{l}\text { Ahli Media } \\
\text { Pembelajaran }\end{array}$ & $\begin{array}{l}\text { Kelayakan Media } \\
\text { Pembelajara }\end{array}$ & $\begin{array}{l}\text { Untuk mengamati apakah media } \\
\text { pembelajaran tersebut sesuai atau } \\
\text { sudah layak digunakan }\end{array}$ & 93,18 \\
\hline 3 & $\begin{array}{l}\text { Ahli Desain } \\
\text { Pembelajaran }\end{array}$ & $\begin{array}{l}\text { Kelayakan Desain } \\
\text { Pembelajaran }\end{array}$ & $\begin{array}{l}\text { Untuk mengamati apakah desain } \\
\text { pengembangan sudah sesuai dengan } \\
\text { prosedur yang digunakan, sehingga } \\
\text { dikategorikan layak }\end{array}$ & 92,50 \\
\hline 4 & $\begin{array}{l}\text { Coba } \\
\text { Perorangan }\end{array}$ & Kejelasan Fisik & $\begin{array}{l}\text { Untuk mengidentifikasi dan } \\
\text { menghapus kesalahan yang mencolok } \\
\text { dalam pengajaran serta untuk } \\
\text { mendapatkan indikasi awal dan reaksi } \\
\text { para pelajar terhadap isi. }\end{array}$ & 100 \\
\hline 5 & Kelompok Kecil & $\begin{array}{ll}\text { Minat dan } \\
\text { Ketertarikan }\end{array}$ & $\begin{array}{l}\text { Unutuk mengamati apabila pelajar } \\
\text { mengalami kemandekan dalam proses } \\
\text { belajarnya dan tidak dapat } \\
\text { melanjutkannya, barulah instruktur ini } \\
\text { terlibat. }\end{array}$ & 82,81 \\
\hline 6 & Lapangan & Efektifitas & $\begin{array}{l}\text { Untuk menentukan apakah } \\
\text { perubahan-perubahan di dalam } \\
\text { instruksi tersebut harus dibuat setelah } \\
\text { tahap kelompok kecil tersebut } \\
\text { menjadi efekti }\end{array}$ & 90,38 \\
\hline
\end{tabular}

Hasil akhir dari pengembangan bahan ajar muatan lokal menghasilkan produk dengan bentuk sebagai berikut:

1. Identitas Produk

Bentuk

: Cetak

Judu

: BAHASA BU-

Sasaran

\section{OL}

: Siswa Kelas 1

Semster 1 SD/MI

di Kabupaten Buol

Nama pengarang : Hariyanto S. Auna

Tebal halaman : 57 halaman

Ukuran keras : $21 \mathrm{~cm}$ x 29,7 $\mathrm{cm} / 210 \mathrm{~mm} \quad \mathrm{x}$

$297 \mathrm{~mm}$ format

A4

Jenis Huruf dan Font

- Judul Buku $\quad: \quad$ Calibri
(Body) 48 pt

- Heading : Calibri (Body) $36 \mathrm{pt}$

- Sub Heading : Calibri (Body) 20 $\mathrm{pt}$

- Uraian Materi $\quad$ : Calibri (Body) 20 pt

- Spasi :1,15 spasi

2. Karakterstik Produk

a. Ukuran Produk

Ukuran kertas yang digunakan untuk mencetak bahan ajar ini adalah A4 (210 mm x $297 \mathrm{~mm}$ ). Penggunaan ukuran A4 ini dengan alasan kemenarikan dan efisiensi. Walau tidak ada ketentuan khusus dalam pemilihan ukuran halaman, namun pemilihan ukuran halaman ini sangat perlu untuk diperhatikan. Ukuran kertas A4 dipilih dikarenakan menurut pengembang, ukurannya cukup repesen- 
tatif atau sesuai dan memadai untuk melakukan kreasi dan ekspolorasi dalam mengembangkan desain dan tata letak penulisan, ilustrasi dan lain sebagai juga tidak terlalu kecil dan tidak terlalu besar, sehingga cukup sesuai dengan siswa.

b. Pemilihan gambar yaitu dengan menggunakan gambar-gambar berbentuk kartun. Pemiliha gambar tersebut dikarenakan hasil analisis perilaku siswa secara teori dan pengamatan serta masukan ahli.

c. Pendekatan kognitif dalam baha ajar, dikarenakan hasil analisis pembelajaran dan analisis prilaku siswa. Hal ini dikarenakan bahasa bagian dari kemampuan berpikir untuk memahami lingkungan melalui, simbol-simbol, kode da tanda. Selain itu siswa SD dengan usia 6-9 tahun dalam tahap pengenalan.

\section{SIMPULAN DAN SARAN Saran Pemanfaatan}

Saran pemanfaatan produk
bangan bahan ajar muatan lokal pengembangan bahan ajar muatan lokal bahasa Buol yaitu sebagai berikut.

a. Bahasa dan cara berfikir anak per berbeda dengan orang dewasa. sejenis. Aspek yang dirasakan perlu Oleh karena itu guru mengajar diantaranya.

dengan menggunakan bahasa yang a. Produk ini perlu diseminarkan sesuai dengan berfikir anak.

b. Faktor kognitif merupakan jendela bagi masuknya berbagai penge- $b$. tahuan siswa melalui kegiatan belajar baik secara mandiri maupun secara kelompok.. Oleh karena itu siswa ditekankan pada kegiatan mengingat, memahami, mengaplikasikan, menganalisis mengevaluasi dan mencipta dalam kegiatan pembelajaran

c. Dibutuhkan pendampingan guru dalam setiap pembelajaran sehi- ngga siswa memahami setiap langkah-langkah dalam melaksanakan setiap perintah dalam bahan ajar. Oleh karena itu guru harus memiliki RPP dan alat evaluasi proses kegiatan pembelajaran.

\section{Desiminasi}

Produk ini dirancang untuk dapat membantu siswa memiliki kemampuan dan pengetahuan serta minat dalam berbahasa Buol, sehingga dikembangkan bahan ajar dengan proses kognitif secara sistematis. Produk bahan ajar ini dirancang sesuai dengan analisis kebutuhan, karakteristik target pengguna, serta kondisi lingkungan di siswa yang ada di Kabupaten Buol. Apabila produk ini akan digunakan pada sekolah yang ada di luar daerah Buol, kemungkinan akan kesulitan dalam mempelajarinya.

1. Pengembangan Produk Lebih Lanjut

Meskipun catatan hasil uji coba berdasarkan data yang di dapat dari ahli media, ahli materi, dan ahli desain serta uji coba lapangan menunjukan tingkat kevalidan, namun pengembang masih menyadari akan beberapa aspek yang dirasakan perlu ada peningkatan dalam kembali di daerah Kabupaten Buol dan dilakukan uji coba kembali Isi materi dan ranah pembelajaran hanya pada kelas satu sekolah dasar, sehingga pengembangan produk ini dapat menjadi acuan patokan untuk mengembangkan ketingkat berikutnya.

\section{DAFTAR RUJUKAN}

Peraturan Pemerintah Republik Indonesia Nomor 32 Tahun 2013 tentang Perbahan atas Peraturan 
279 Jurnal Inovasi dan Teknologi Pembelajaran, Volume 2, Nomor 1, Oktober 2015, hlm. 205-291

Pemerintah Nomor 19 Tahun 2005

Tentang Standar Nasional.

Pendidikan. Badan Standar

Nasional Pendidikan (Online).

(http://bsnp-indonesia.org/id/wp-

content/uploads/2013/05/PP.pdf).

Diakses 4 Agustus 2014.

Peraturan Pemerintah Republik

Indonesia Nomor 57 Tahun 2014

tentang Pengembangan, dan

Perlindungan Bahasa dan Sastra

serta Peningkatan Fungsi Bahasa

Indonesia. (Online),

(http://jdih.ristek.go.id/?q=system/

files/rencana-

kebijakan/12266277776.pdf)

Santrock, Jhon W. 2008. Psikologi

Pendidikan, Edisi Kedua.

Jakarta: Kencana 